\title{
PRAVNO UREĐENJE PRISTUPA TRŽIŠTU TEHNIČKO-NAUTIČKIH LUČKIH DJELATNOSTI U PRAVU EUROPSKE UNIJE I HRVATSKOM PRAVU I NJEGOVE POSLJEDICE U PRAKSI
}

Dr. sc. Božena Bulum*
Doc. dr. sc. Marija Pijaca**

UDK: 379.846 (497.5:4EU)

$347.79: 338.48(497.5)$

338.48::797.1(497.5)

339.923:061.1>(4)EU

DOI: 10.3935/zpfz.70.1.02

Izvorni znanstveni rad

Primljeno: ožujak 2020.

Predmet ovog rada je pristup tržištu i organizacija pružanja tehničko-nautičkih lučkih usluga u pravu Europske unije i Republike Hrvatske. Počevši od 1997. godine, kada je donesena Zelena knjiga o morskim lukama i pomorskoj infrastrukturi (Zelena knjiga) te je najavljeno donošenje europskog zakonodavstava primjenjivog na lučki sektor, ta su pitanja prouzročila najviše sporova među dionicima. Posljedično, prvi pravni akt sekundarnog prava Europske unije o pristupu tržištu lučkih usluga, Uredba 2017/352 o uspostavi okvira za pružanje lučkih usluga i zajedničkih pravila o financijskoj transparentnosti luka, donesena je tek dvadeset godina nakon Zelene knjige. Međutim, tom su Uredbom pitanja pristupa tržištu tehničko-nautičkih lučckih usluga samo djelomično regulirana. Iz tog se razloga u članku osim Uredbe 2017/352 analiziraju svi relevantni izvori prava Europske unije i Republike Hrvatske te se podnose prijedlozi za njihovo unaprjeđenje.

Ključne riječi: tehničko-nautičke lučke djelatnosti; pristup tržištu; Uredba 2017/352; univerzalne usluge; usluge od općeg gospodarskog interesa

* Dr. sc. Božena Bulum, znanstvena savjetnica u Jadranskom zavodu Hrvatske akademije znanosti i umjetnosti, Augusta Šenoe 4, Zagreb; bbulum@hazu.hr;

ORCID ID: orcid.org/0000-0003-4606-9815

** Dr. sc. Marija Pijaca, docentica Pomorskog odjela Sveučilišta u Zadru, Mihovila Pavlinovića 1; mpijaca@unizd.hr;

ORCID ID: orcid.org/0000-0002-0709-376X 


\section{UVOD}

Pojam tehničko-nautičkih lučkih usluga (djelatnosti) pomoćnih u navigaciji odnosno plovidbi (engl. tehnical-nautical services ancillary to navigation) ${ }^{1}$ prvi se put spominje u talijanskoj pravnoj znanosti kao zajednički naziv za usluge koje se pružaju brodovima kako bi im se olakšalo izvođenje manevara u lučkom akvatoriju i na plovnom putu za pristup luci. On obuhvaća tehničko-nautičke lučke usluge peljarenja, tegljenja te priveza i odveza brodova.

Peljarenje ili pilotaža (engl. pilotage, franc. pilotage, njem. Lotsendienst, tal. pilotaggio) je vođenje plovnog objekta od stručnih osoba (peljara, pilota) i davanje stručnih savjeta zapovjedniku plovnog objekta radi sigurne plovidbe u lukama, tjesnacima i drugim područjima opasnim ili zahtjevnim za plovidbu. Peljarenje može biti prema području na kojem se obavlja obalno ili lučko, a prema obvezatnosti obvezno ili dobrovoljno. Peljarenje je obvezatno na mjestima osobito opasnim za plovidbu, mjestima s velikom gustoćom prometa ili tamo gdje to nalažu posebni interesi sigurnosti obalne države. ${ }^{2}$

Za tegljenje (engl. towing, towage, franc. touage, remorquage, njem. Schleppen, tal. rimorchio) kao poseban oblik brodarske djelatnosti karakteristično je da brod koji tegli (tegljač, remorker) stavlja tegljenom brodu ili drugom pomorskom objektu na raspolaganje svoju pogonsku snagu na način da ga povlači ili potiskuje (gura). ${ }^{3}$ Specifičnost lučkog tegljenja jest da ono služi obavljanju manevra broda koji najčešće ima vlastiti pogon. Kod lučkog tegljenja tegljač tegljenom

1 Vidi Carbone, M. S.; Munari, F., Port services ancillary to navigation between market and safety requirements, Lloyd's Maritime and Commercial Law Quarterly, br. 1, 1996. str. 67 - 92. Naziv je prihvatila Europska komisija te ga je koristila u svojim aktima kojima se regulira lučka politika Europske unije.

2 Pomorci su se od davnina, prilikom prolaska kroz mjesta opasna za plovidbu, obraćali za pomoć osobama koje dobro poznaju prilike određenog mjesta da ih provedu kroz opasno područje kako bi izbjegli moguća oštećenja broda. Tako se peljarenje spominje već u odredbama statuta srednjovjekovnih gradova (Statut Dubrovnika, knj. VII, čl. 56.; Hvara, knj. V, čl.10; Kotora, čl. 379.). Vidi Pomorska enciklopedija, I. izdanje, sv. 6., Leksikografski zavod, Zagreb, 1960., str. 100. O peljarenju u okviru poglavlja o pravnim aspektima sigurnosti plovidbe pišu Jakaša, B., Udžbenik plovidbenog prava, I. izdanje, Narodne novine, Zagreb, 1983., str. 59; Grabovac, I., Plovidbeno pravo Republike Hrvatske, Književni krug, Split, 2006., str. 57.

3 Kao poseban oblik brodarske djelatnosti tegljenje je nastalo pojavom brodova na parni pogon. Opširnije Pomorska enciklopedija, sv. 8., II. izdanje, Leksikografski zavod, Zagreb, 1988., str. 89; Pavić, D., Pomorsko imovinsko pravo, Književni krug, Split, 2006., str. 275; Ivošević, B.; Pejović, Č., Pomorsko pravo, Pravni fakultet Univerziteta Union u Beogradu, Javno poduzeće Službeni glasnik, Beograd, 2019., str. 509. 
brodu olakšava manevar ulaženja u luku, prolaza kroz luku, pristajanja uz obalu, pomicanje s obale na obalu ili odlaska iz luke. Tegljenje također može biti dobrovoljno ili obvezatno. ${ }^{4}$

Privez (engl. mooring, franc. amarage, njem. Bindensdienst, tal. ormeggio) obuhvaća usluge privezivanja i odvezivanja, uključujući premještanje uz pristanište, potrebne za sigurno upravljanje plovilom u luci ili na plovnom putu za pristup luci. ${ }^{5}$

Usluge tehničko-navigacijskog (nautičkog) karaktera pružaju se brodovima kako bi se postigla sigurnost plovidbe u lukama i plovnim putovima za pristup lukama te posljedično sigurnost osoba, lučkih uređaja i postrojenja, zaštita okoliša i sigurnosna zaštita luka.

Dok je većina ostalih lučkih usluga namijenjena teretu i imaju naglašen gospodarski karakter, pa je pristup tržištu tih usluga (engl. market access) i opskrbu tim uslugama (engl. supply) moguće organizirati prema kompetitivnom modelu, tehničko-nautičke usluge fokusirane su na sigurnost, zbog čega se na njih primjenjuje poseban pravni režim. Razlog tome je što se zadovoljavajuća razina kvalitete te dostupnost tehničko-nautičkih usluga za sve brodove u određenoj luci, u bilo koje vrijeme, u pravilu ne može osigurati redovitim funkcioniranjem tržišta, već je potrebna intervencija javnih tijela na tržištu tih usluga. Posljedica toga jest da države članice Unije imaju široku diskreciju u oblikovanju pravila o pristupu tržištu tih usluga i općenito organizaciji njihova pružanja.

Rad je posvećen analizi pravnog uređenja pitanja pristupa tržištu i organizacije pružanja tehničko-nautičkih lučkih djelatnosti u pravu Europske unije (dalje u tekstu: Unija, EU) i hrvatskom pravu. Analiziraju se svi relevantni izvori prava Unije i Republike Hrvatske (dalje u tekstu: RH) koji uređuju predmetnu materiju. Osim toga, razmatra se postojeća praksa pružanja tehničko-nautičkih lučkih usluga u hrvatskim lukama otvorenim za javni promet te se ocjenjuje njezina usklađenost s važećim nacionalnim i europskim pravom. U tom kontekstu u radu se daje odgovor na pitanja mogu li lučke uprave u RH imati funkciju lučkog operatera odnosno pružatelja tehničko-nautičkih lučkih usluga sukladno odredbama primjenjivog nacionalnog i europskog prava te jesu li one dužne te usluge pružati u bilo koje vrijeme (engl. provision on round the clock-round the year basis) i svim brodovima u luci. Također, cilj je rada odgovoriti na pitanje imaju li korisnici luke, osobito brodari, pravo pristupa tržištu tehničko-nautičkih usluga

4 Jakaša, op. cit. u bilj. 2, str. 300.

5 Vidi čl. 2. st. 6. Uredbe (EU) 2017/352 Europskog parlamenta i Vijeća od 15. veljače 2017. o uspostavi okvira za pružanje lučkih usluga i zajedničkih pravila o financijskoj transparentnosti luka, SL L 57, 3. 3. 2017, str. 1 - 18. (dalje u tekstu: Uredba 2017/352). 
u RH, odnosno može li posada brodova samostalno obavljati tu vrstu usluga za brodove koje brodari iskorištavaju za pružanje usluga prijevoza morem. Naposljetku, ocjenjuje se adekvatnost postojećih pravnih pravila kojima se uređuje pružanje te vrste usluga te se daju prijedlozi za njihovo unaprjeđenje.

\section{SPECIFIČNA OBILJEŽJA TEHNIČKO-NAUTIČKIH LUČKIH DJELATNOSTI I NJIHOVE PRAVNE POSLJEDICE}

Iako tehničko-nautičke lučke usluge čine gospodarsku djelatnost ${ }^{6}$ jer je riječ o tržišnim uslugama, one se, za razliku od većine ostalih lučkih usluga namijenjenih teretu ${ }^{7}$, pružaju brodovima s ciljem postizanja sigurnosti plovidbe u luci. To opravdava uvođenje posebnog pravnog režima za tu vrstu lučkih usluga u odnosu na ostale lučke usluge.

Iz tog razloga države članice kao uvjet za pristup tržištu tih usluga redovito zahtijevaju posjedovanje specifičnih znanja i vještina iz područja nautike te profesionalizam njihovih pružatelja, tj. završeno srednjoškolsko obrazovanje nautičkog smjera ili završeni preddiplomski sveučilišni studij nautičkog smjera i određeni plovidbeni staž. ${ }^{8}$

Osim izobrazbe određenog smjera i stupnja pružatelji lučkih usluga tehničko-nautičkog karaktera moraju poznavati i lokalne uvjete ${ }^{9}$, tj. zemljopisne, hidrografske, hidrometeorološke i druge uvjete luke u kojoj se te usluge pružaju.

6 Ustaljena je sudska praksa kako sve djelatnosti koje se sastoje od ponude robe i usluga na tržištu čine gospodarsku djelatnost. Vidi odluke u predmetima C-118/85 Komisija/Italija, ECLI:EU:C:1987:283, t. 7. i C-35/96 Komisija/Italija, ECLI:EU:C:1998:303, t. 36.

7 Lučke usluge rukovanja teretom obuhvaćaju organizaciju i rukovanje teretom između plovila kojim se teret prevozi i obale, bilo za uvoz, izvoz ili provoz tereta, uključujući obradu, privezivanje, odvezivanje, slaganje tereta, prijevoz i privremeno pohranjivanje tereta na odgovarajućem terminalu za rukovanje teretom, a izravno povezano s prijevozom tereta, ali isključujući, osim ako država članica odredi drukčije, skladištenje, pražnjenje, ponovno pakiranje ili bilo koju drugu uslugu s dodanom vrijednošću povezanu s teretom kojim se rukuje (čl. 2. 2. Uredbe 2017/352).

8 Kao primjer država u kojima su profesionalni zahtjevi koje trebaju ispunjavati pruŽatelji svih vrsta tehničko-nautičkih lučkih usluga propisani općim propisima primjenjivim na čitavom teritoriju države članice navode se države čije luke su među najprometnijima u Uniji. To su, primjerice, Italija, Francuska i Španjolska. Carbone; Munari, op. cit. u bilj. 1, str. 71 .

9 Grabovac to naziva "maritimno-nautičkim mjesnim prilikama". Vidi Grabovac, op. cit. u bilj. 2, str. 58 . 
Nadalje, specifičnost tehničko-nautičkih lučkih usluga u odnosu na druge lučke usluge jest i ta da one zbog ciljeva koji se njima ostvaruju (sigurnost plovidbe, zaštita okoliša i sigurnosna zaštita) trebaju biti dostupne svim brodovima u luci u bilo koje vrijeme (24 sata dnevno, 365 dana u godini). U tom kontekstu pravni teoretičari ističu upravo dostupnost (engl. availability) tehničko-nautičkih lučkih usluga kao temeljni preduvjet sigurnosti u luci. ${ }^{10}$

One usluge koje karakterizira potreba za dostupnošću usluge svim njezinim korisnicima, kontinuirano, u bilo koje vrijeme u pravu Unije obuhvaćene su pojmom univerzalnih usluga. Kako bi se osiguralo pružanje univerzalne usluge, potrebna je državna intervencija na tržištu određene usluge zato što se univerzalnost usluge, u pravilu, ne može postići njegovim redovitim funkcioniranjem. Zbog toga javna tijela država članica EU-a (na nacionalnoj, regionalnoj ili lokalnoj razini) trebaju intervenirati i u općem interesu organizirati i financirati pružanje univerzalne usluge. Javna intervencija sastoji se u tome da javna tijela nametnu obvezu pružanja univerzalne usluge (engl. universal service obligation) jednom ili više poduzetnika na određenom tržištu (primjerice, jednom ili više pružatelja određene tehničko-nautičke usluge u luci) ili da ona sama pružaju tu uslugu.

Univerzalne usluge pripadaju u javne usluge. U pravu Unije ponajprije se koristi termin usluge od općeg interesa (engl. services of general interest, dalje u tekstu; UOI) ${ }^{11}$ kao europska alternativa pojmu javne usluge ili službe (franc. service public) koji potječe iz francuskog upravnog prava. ${ }^{12}$ Usluge od općeg interesa mogu biti gospodarske (usluge od općeg gospodarskog interesa, engl. services of general economic interest, dalje u tekstu; UOGI), negospodarske i socijalne (dalje u tekstu:

10 Vidi Carbone, M. S.; Munari, F., The Regime of Technical-Nautical services (Pilotage, Towage, Mooringmen) under European law u: Van Hooydonk, E. (ur.), European Seaports Law, EU Law of Ports and Ports Services and the Ports Package, Malu, Antwerpen - Apeldoorn, 2003., str. 201.

11 Pobliže o UOI-ju vidi u sljedećim Komisijinim aktima: Komunikacija Komisije o primjeni pravila EU-a o državnim potporama na naknade koje se dodjeljuju za obavljanje UOGI-ja (SL C 8, 11. 1. 2012., str. 4, dalje u tekstu: Komunikacija o UOGIjima); Komunikacija Komisije - Okvir Europske unije za državnu potporu u obliku naknade za javne usluge (SL C 8, 11. 1. 2012., str. 15); Komunikacija Komisije - Okvir za upravljanje kvalitetom UOGI-ja, 20. 12. 2011., COM (2011.) 900 final; Radni dokument Komisije - Vodič za primjenu pravila EU-a o državnim potporama, javnim nabavama i unutarnjem tržištu na UOGI-ju, posebno na SUOI-ju, (SWD (2013) 53 final/2, dalje u tekstu: Vodič za primjenu pravila EU-a na UOGI i SUOI).

12 De Groot, M., Supervision on Public Service Performance by Private Providers: the Relevance of EU Law, European Procurement \& Public Private Partnership Law Review, vol. 10, br. 4, 2015., str. $243-253$. 
SUOI). ${ }^{13}$ Obveza univerzalne usluge Komisijinom je Komunikacijom - Okvir za upravljanje kvalitetom UOGI-ja definirana kao vrsta obveze pružanja javne usluge ${ }^{14}$ koja podrazumijeva da određene vrste usluga specificirane kvalitete trebaju biti dostupne svim korisnicima u državi članici neovisno o njihovoj fizičkoj lokaciji te, uzimajući u obzir specifične nacionalne okolnosti, i po pristupačnim cijenama. ${ }^{15}$ Pritom je tržišna cijena pružanja tih usluga niža od njihove ekonomske cijene, čime se stvara gubitak koji je potrebno nadoknaditi. ${ }^{16} \mathrm{Zbog}$ toga javna tijela u državama članicama financijski podupiru pružanje univerzalnih usluga ${ }^{17}$ Definicija specifičnih obveza univerzalne usluge na razini Unije utvrđena je liberalizacijskim direktivama kao bitna komponenta liberalizacije tržišta u pojedinim sektorima kao što su poštanske usluge, elektroničke komunikacije i transport. Kako je liberalizacija unutarnjeg tržišta Unije na području lučkih usluga provedena Uredbom 2017/352, pravila te Uredbe primjenjuju se na pitanja pristupa tržištu i naplaćivanja tehničko-nautičkih lučkih usluga.

\section{EVOLUCIJA PRAVNOG UREĐENJA PRISTUPA TRŽIŠTU TEHNIČKO-NAUTIČKIH LUČKIH USLUGA U PRAVU UNIJE}

Morske se luke ne spominju ni u jednom od osnivačkih ugovora kojima je počela europska integracija, uključujući i one ugovore na kojima se Unija danas temelji, a to su u prvom redu Ugovor o EU-u i Ugovor o funkcioniranju EU-a. ${ }^{18}$

13 Korištenje termina javna usluga u pravu EU-a nije ujednačeno. Kako bi izbjegla neujednačenost u terminologiji, Europska komisija u svojim aktima koristi termin UOI. Vidi Okvir za upravljanje kvalitetom UOGI-ja, cit. u bilj. 11, str. 4.

14 U sudskoj praksi govori se o obvezi pružanja javnih usluga, što može biti jedan od načina povjeravanja obavljanja UOI-ja i UOGI-ja. Vidi presudu u predmetu C280/00 Altmark Trans i Regierungspräsidium Magdeburg, EU:C:2003:415, t. 87. i 88.; Stanković, D., Uloga postupaka javne nabave u financiranju usluga od općeg gospodarskog interesa, Zagrebačka pravna revija - Elektronički časopis poslijediplomskih studija Pravnog fakulteta Sveučilišta u Zagrebu, vol. 7, br. 1, 2017., str. 57.

15 Okvir za upravljanje kvalitetom UOGI-ja, cit. u bilj. 11, str. 4.

16 O univerzalnoj usluzi u svezi s elektroničkim komunikacijskim mrežama vidi Radionov, N., Financiranje univerzalne usluge širokopojasnog pristupa internetu: novi izazovi za Hrvatsku, Zagrebačka pravna revija - Elektronički časopis poslijediplomskih studija Pravnog fakulteta Sveučilišta u Zagrebu, vol. 6, br. 2, 2017., str. 147 - 174.

17 Opširnije o tome pod kojim uvjetima su te potpore dopuštene vidi presudu u predmetu C280/00 Altmark, cit. u bilj. 14; Stanković, op. cit. u bilj. 14, str. 53 - 69.

18 Vidi SL C 202 (pročišćeni tekst), str. 13 - 47 (dalje u tekstu: UFEU) i SL C 202 (pročišćeni tekst), 7. 6. 2016., str. 47 - 201 (dalje u tekstu: UEU). 
Kada se govori o početku kreiranja europske lučke politike, važna je 1977. godina. Te je godine radna skupina koju je osnovala Europska komisija izradila izvješće o financijskim i pravnim odnosima u morskim lukama (engl. Fact Finding Report) na temelju kojeg je Komisija zauzela stajalište kako još nije potrebno donošenje specifičnog sektorskog zakonodavstva Unije za morske luke. Nakon što je 90-ih godina donesen niz odluka Suda ${ }^{19}$ i Europske komisije u svezi s ograničenjem slobode pružanja usluga i slobode tržišnog natjecanja u talijanskim morskim lukama ${ }^{20}$, to je stajalište promijenjeno te je 1997. godine Komisija objavila Zelenu knjigu o morskim lukama i pomorskoj infrastrukturi (dalje u tekstu: Zelena knjiga). ${ }^{21}$ Zelenom knjigom pokrenuta je rasprava o mogućem donošenju europskog zakonodavstva za lučki sektor. Pristup tržištu lučkih usluga, odnosno liberalizacija tog tržišta područje je kojem je Komisija dala prioritet. U svezi s pitanjem regulacije tehničko-nautičkih lučkih djelatnosti u Zelenoj je knjizi navedeno kako se te djelatnosti razlikuju od ostalih lučkih djelatnosti jer se vrše u korist brodova koji pristaju u luci. Istaknuta je njihova važnost za postizanje sigurnosti brodova, tereta, putnika i lučke zajednice u cjelini zbog čega je potrebno njihovo kontinuirano obavljanje, što bi moglo dovesti do ograničenog pristupa tržištu tehničko-nautičkih lučkih djelatnosti u nekim lukama Unije. ${ }^{22}$

Nakon toga Komisija je u dva navrata podnosila Vijeću ministara i Parlamentu prijedloge za donošenje Direktive o pristupu tržištu lučkih usluga. Prvi put 2001.

19 Uslijed reorganizacije sudova EU-a Sud EU-a (The Court of Justice of the European Union) kao jedinstvenu instituciju čine dva suda, Opći sud (The General Court) i Sud (The Court of Justice). Stoga dalje u tekstu pozivanje na sudsku praksu Suda EU-a obuhvaća sudsku praksu i Općeg suda i Suda, dok pozivanje na Sud, odnosno Opći sud, znači pozivanje samo na pojedinačnu sudsku instancu unutar Suda EU-a.

20 Opširnije vidi Radionov, N. et al., Europsko prometno pravo, Pravni fakultet Sveučilišta u Zagrebu, Zagreb, 2011., str. 309.

${ }^{21}$ Zelena knjiga o morskim lukama i pomorskoj infrastrukturi, 10. 12. 1997., COM (97) 678 final. Prema Zelenoj knjizi zajednička europska lučka politika trebala je obuhvaćati tri područja. To su povezivanje luka u transeuropsku transportnu mrežu, financiranje i naplaćivanje lučkih djelatnosti te pristup tržištu lučkih djelatnosti. Uredba 2017/352, donesena dvadeset godina nakon Zelene knjige, regulira ista pitanja koja su otvorena Zelenom knjigom.

22 Zelena knjiga, t. 85 - 90. Van Hooydonk, E., The Regime of Port Authorities under European Law (including an Analysis of Port Services Directive) u: Van Hooydonk, E. (ur.), European Seaports Law, EU Law of Ports and Ports Services and the Ports Package, Malu, Antwerpen - Apeldoorn, 2003., str. 96. 
godine $^{23}$, a zatim i 2004. godine (Prijedlozi I. i II.). Međutim, oni nisu izglasani u Europskom parlamentu. Oba prijedloga sadržavala su pravila o pristupu tržištu svih lučkih usluga, uključujući i onima tehničko-nautičkog karaktera. Taj je pristup bio uvjetovan obvezom ishođenja odobrenja (engl. authorisation) za obavljanje lučkih djelatnosti (Prijedlogom I. samo u slučaju ograničenja broja pružatelja usluge) koje je bilo vremenski ograničeno. ${ }^{24}$ Nadalje, oba prijedloga sadržavala su odredbe o provođenju tzv. objektivnog postupka odabira lučkog operatera (engl. objective selection procedure), financijskoj transparentnosti luka, pravu lučkih operatera na slobodan odabir svog osoblja te odredbe o pravu korisnika luke da samostalno obavljaju lučke djelatnosti (engl. self-handling). ${ }^{25}$ Pravni teoretičari upozoravali su kako Komisijino nepoštovanje ovlasti država članica da tehničko-nautičke lučke usluge definiraju kao UOGI i organiziraju njihovo pružanje u skladu s člankom 106. UFEU-a utječe na podjelu ovlasti između država članica i Komisije te da se na taj način krši načelo supsidijarnosti utvrđeno u čl. 5. st. 3. UEU-a. ${ }^{26}$ Uz iznimku za peljarenje ${ }^{27}$ Komisijinim prijedlozima nisu bila predviđena posebna pravila za samostalno obavljanje

23 Komunikacija Komisije - Poboljšanje kvalitete lučkih usluga: ključ za europski transport, 13. 2. 2001., COM (2001) 35 final. Ta je komunikacija nazvana prvi lučki paket (engl. Port Package I). Vidi Bulum, B., Pravo tržišnog natjecanja Europske zajednice i morske luke, Zbornik Pravnog fakulteta u Zagrebu, vol. 58, br. 1-2, 2008., str. 624.

24 Pobliže vidi Van Hooydonk, E., The Europen Port Services Directive: the Good or the Last Try?, Il diritto marittimo, br. 1, 2006., str. 66.

25 Koncept samostalnog obavljanje usluga preuzet je iz propisa o pristupu tržištu zemaljskih usluga u zračnim lukama Unije, a odnosi se na situaciju u kojoj korisnik zračne luke izravno obavlja sam za sebe jednu ili više kategorija zemaljskih usluga i za pružanje takvih usluga ne zaključuje bilo kakav ugovor s trećom osobom. Vidi čl. 1. st. 1. (f) Direktive Vijeća 96/67/EZ od 15. listopada 1996. o pristupu tržištu zemaljskih usluga u zračnim lukama Zajednice, SL L 272, 25. 10. 1996, str. 36 45. Prijedlozima I. i II. mutatis mutandis bila je predviđena mogućnost samostalnog obavljanja lučkih usluga od strane korisnika luke. Tako je čl. 1. t. 9. Prijedloga II. samostalno obavljanje definirano kao situacija u kojoj poduzetnik koji bi mogao redovito kupiti lučku uslugu obavlja tu uslugu samostalno, koristeći svoje kopneno osoblje i opremu.

26 Vidi Munari, F., The impact on technical-nautical services of the second proposal for a port service directive, Il diritto marittimo, br. 1, 2006., str. 57. Načelo supsidijarnosti primjenjuje se u područjima podijeljenih ovlasti između Unije i država članica te preferira odlučivanje na nacionalnoj, a ne na razini EU-a. Vidi Ćapeta, T.; Rodin, S., Osnove prava Europske unije, III. izmijenjeno i dopunjeno izdanje, Narodne novine, Zagreb, 2018., str. 32.

27 Vidi Prijedlog za donošenje Direktive o pristupu tržištu lučkih djelatnosti, 13. 10. 2004., COM (2004.) 654 final, čl. 14. 
tehničko-nautičkih lučkih usluga. Štoviše, Prijedlogom II. bilo je propisano da će za korisnike luke lučke djelatnosti, pa tako i one tehničko-nautičkog karaktera, obavljati njihovi zaposlenici na kopnu, tzv. kopneno osoblje (engl. land-based personnel), a ne posada broda kojem su te usluge namijenjene, kao što je to predviđao Prijedlog I. Te su odredbe Prijedloga II. naišle na brojne kritike znanstvenika i praktičara, ponajprije sindikata lučkih radnika, koji su svojim akcijama štitili socijalna prava svojeg članstva jer su uvidjeli kako bi primjena odredbi predložene Direktive o pravu samostalnog obavljanja lučkih djelatnosti mogla dovesti do masovnog otpuštanja lučkih radnika. Najviše kritika upućeno je u smjeru odredbi o pravu samostalnog obavljanja lučkih usluga tehničko-nautičkog karaktera. Upozoravalo se na opasnost od gubitka profesionalizma u obavljanju tehničko-nautičkih djelatnosti zato što kopneno osoblje korisnika luke ne posjeduje potrebna znanja i vještine iz područja nautike pa obavljanje tehničko-nautičkih lučkih djelatnosti od strane tog osoblja može ugroziti sigurnost u luci. Posljedično, odredbe o samostalnom obavljanju lučkih usluga imale su presudan utjecaj na to da ni Prijedlog I. ni Prijedlog II. nisu izglasani u Europskom parlamentu. ${ }^{28}$

Nakon neizglasavanja Prijedloga II. Komisija je privremeno odustala od donošenja akata legislativnog karaktera te je objavila Komunikaciju o europskoj lučkoj politici 2007. godine. ${ }^{29} \mathrm{U}$ toj je Komunikaciji istaknuto kako će liberalizacija tržišta tehničko-nautičkih usluga zahtijevati poseban pristup u odnosu na ostale lučke usluge jer je izvjesno da u slučaju potpune liberalizacije tržišta te vrste usluga ne bi došlo do ulaska na tržište novih poduzetnika, nego bi konkurenti postojećim operaterima bili isključivo velike tvrtke već prisutne u prijevoznoj industriji (tzv. globalni prijevoznici) koje bi na taj način proširile svoju djelatnost samostalnim obavljanjem tih usluga te poduzetnici prijevoznih terminala koji bi proširili svoju djelatnost i na tu vrstu usluga.

Međutim, Komisija je ipak 2013. godine ponovno podnijela Europskom parlamentu i Vijeću prijedlog za donošenje zakonodavnog akta, ovaj put Uredbe. Nakon brojnih konzultacija s dionicima (engl. stakeholders) te brojnih kompromisa koji su doveli do toga da su mnogi instituti sadržani Prijedlozima I. i II. izostavljeni, donesena je Uredba 2017/352.

U nastavku ćemo analizirati one izvore prava Unije koji su na snazi, a odnose se na pristup tržištu i organizaciju pružanja tehničko-nautičkih lučkih usluga

28 O akcijama sindikata lučkih radnika usmjerenim protiv Prijedloga II. vidi Leiren, M. D.; Parkes, L., When trade unions succeeded: Cases of blocked liberalisation in the common market, European Journal of Political Research, vol. 53, br. 1, 2014., str. 470. 
u državama članicama Unije. To je u prvom redu Uredba 2017/352, kojom se regulira pristup tržištu tehničko-nautičkih lučkih usluga u Uniji te sudska praksa Suda EU-a koja popunjava postojeću pravnu prazninu koja postoji u odnosu na pitanja samostalnog obavljanja te vrste usluga. Kako su brojna stajališta Suda EU-a ugrađena u Uredbu 2017/352, krenut ćemo od analize sudske prakse.

\subsection{Sudska praksa Suda EU-a primjenjiva na pitanja pristupa tržištu i organizacije pružanja tehničko-nautičkih lučkih usluga}

Važna stajališta kada je riječ o pristupu tržištu tehničko-nautičkih lučkih usluga, primjenjiva i na pitanja pristupa tržištu UOGI-ja općenito, Sud je zauzeo u presudi C-266/96 Corsica Ferries/Ormeggatori ${ }^{30}$, donesenoj o prethodnim pitanjima koja su se pojavila u postupku pred Sudom u Genovi (Tribunale di Genova) u svezi s organizacijom pružanja tehničko-nautičkih lučkih usluga priveza i odveza u lukama Genova i La Spezia.

Među ostalim, pitanje nacionalnog suda Sudu bilo je i postoji li zlouporaba vladajućeg položaja od strane udruženja privezivača kojima su talijanska javna tijela povjerila isključiva prava pružanja usluga priveza i odveza povezanog uz kontejnerski prijevoz u lukama Genova i La Spezia. Jedan od mogućih oblika zlouporabe vladajućeg položaja, koji je Sud ispitivao u ovom predmetu, odnosi se na sprečavanje brodarskih društava da samostalno obavljaju privez i odvez svojih brodova koristeći vlastito osoblje. Sud je zauzeo stajalište kako su usluge priveza i odveza UOGI na koje se primjenjuje članak 106. stavak 2. UFEU-a (tada članak 86. stavak 2. Ugovora o Europskoj zajednici) te da one podliježu primjeni pravila tog Ugovora, osobito primjeni pravila o tržišnom natjecanju, u mjeri u kojoj njihova primjena ne sprječava de iure ili de facto obavljanje tih usluga. ${ }^{31}$ To je zbog toga što je poduzetnik koji ih pruža obvezan u bilo koje doba bilo kojem korisniku luke pružiti univerzalnu uslugu priveza i odveza ${ }^{32}$, a

30 Vidi presudu u predmetu C-266/96 Corsica Ferries France SA/Gruppo Antichi Ormeggiatori del porto di Genova Coop. arl, Gruppo Ormeggiatori del Golfo di La Spezia Coop. i dr., ECLI:EU:C:1998:306.

31 Uvjet za primjenu izuzeća iz članka 106. stavka 2. UFEU-a jest da ono ne utječe na razvoj trgovine u mjeri u kojoj bi to bilo suprotno interesima Unije.

32 Na temelju stajališta zauzetih u sudskoj praksi Suda u talijanskoj je pravnoj teoriji detaljno opisano što obuhvaća obveza pružanja univerzalne lučke usluge priveza i odveza, a što je primjenjivo i na ostale usluge tehničko-nautičkog karaktera. "Kao prvo, te se usluge trebaju pružiti svakom onom tko ih zatraži, a to može biti bilo koji korisnik luke. Njima se jamči maksimalna prilagodljivost korisniku; on može doći bilo kojim brodom, s bilo kojom posadom, u bilo kojim vremenskim uvjetima, 
obvezan je obavljati i niz s njima povezanih usluga važnih za sigurnu plovidbu u luci i zaštitu okoliša. Sud je uvažio odluku nadležne lučke uprave da se zbog zaštite javne sigurnosti lokalnim poduzetnicima (udruženjima privezivača) povjere isključiva prava obavljanja univerzalne usluge priveza i odveza brodova u lukama pod njezinom upravom. ${ }^{33}$

Također, iz sudske prakse Suda proizlazi kako se tehničko-nautičke lučke usluge mogu pružati prema modelu koji odstupa od kompetitivnog modela, što može uključivati povjeravanje isključivog prava obavljanja univerzalne usluge određenom lučkom operateru, odnosno monopolni položaj pojedinog pružatelja tehničko-nautičkih usluga u određenoj luci. ${ }^{34}$ Osim monopolne strukture tržišta, nadležna nacionalna tijela mogu propisati i obvezu korištenja korisnika luke tehničko-nautičkim lučkim uslugama (svim uslugama ili jednom vrstom tih usluga) te zabraniti njihovo samostalno obavljanje brodarima ako je to opravdano radi zaštite javne sigurnosti. ${ }^{35}$ Jednako tako, iz sudske prakse proizlazi kako je legitimno pravo država članica propisati minimalne profesionalne kvalifikacije koje radnici zainteresirani za pružanje tehničko-nautičkih usluga moraju posjedovati te ograničiti pristup tržištu tih usluga onim fizičkim ili pravnim osobama koje ne garantiraju da će za pružanje tih usluga zaposliti osoblje koje ih posjeduje. ${ }^{36} \mathrm{~S}$ ciljem zaštite korisnika tehničko-nautičkih usluga u sudskoj praksi Suda osobito se naglašava dužnost poštovanja načela nediskriminacije i jednakosti postupanja pružatelja tih usluga prema njihovim korisnicima. S tim u svezi, iz sudske prakse također proizlazi kako tarife koje se naplaćuju za pružene tehničko-nautičke lučke usluge trebaju biti nediskriminirajuće u odnosu na sve

usluga će svejedno biti pružena. Nadalje, one se pružaju prema unaprijed propisanim pravilima o kvaliteti usluga i postupku njihova obavljanja. Tarife za te usluge unaprijed su određene i jednake su za istu vrstu korisnika te se u većini slučajeva određuju prema prosječnim troškovima pružanja usluge. Tarife također moraju biti pristupačne korisnicima. Osim toga, usluge se trebaju pružati 24 sata dnevno, 365 dana godišnje, bez prekida, a pružatelji usluga odgovorni su lučkoj upravi te su obvezni pomoći joj u slučaju interventnih situacija u luci." Vidi Carbone; Munari, op. cit. u bilj. 10, str. 197.

33 Vidi predmet C-266/96 Corsica Ferries/Ormeggatori, cit. u bilj. 30, t. 45, 60 i 61.

34 C-266/96 Corsica Ferries/Ormeggatori, cit. u bilj. 30, t. 41; C-163/96 Silvano Raso i dr., ECLI:EU:C:1998:54, t.23-25.; C-179/90 i Merci convenzionali porto di Genova SpA v Siderurgica Gabrielli SpA., ECLI:EU:C:1991:464, t. 14 i 19.

35 Vidi spojene predmete C-430/99 i C-431/99 Inspecteur van de Belastingdienst Douane, district Rotterdam v Sea-Land Service Inc. and Nedlloyd Lijnen BV., ECLI:EU:C:2002:364, t.40-44.; C-266/96 Corsica Ferries/Ormeggatori, cit. u bilj. 30, t. 60 i 61; C-18/93 i Corsica Ferries Italia Srl v Corpo dei Piloti del Porto di Genova, ECLI:EU:C:1994:195, t. 45. 
korisnike. ${ }^{37}$ Nadalje, one trebaju biti određene prema transparentnoj proceduri koja omogućuje trećima ocjenu njihove usklađenosti sa stvarnim troškovima pružanja tih usluga, uzimajući u obzir i interese različite od interesa pružatelja usluge, kao što je interes univerzalnog pružanja tehničko-nautičke lučke usluge. ${ }^{38}$

Kvalifikacija tehničko-nautičkih lučkih usluga priveza i odveza, a što je primjenjivo i na ostale vrste tehničko-nautičkih lučkih usluga kao UOGI-ja ima značajne posljedice kada je riječ o pristupu tržištu te općenito organizaciji pružanja te vrste usluga. Zbog toga ćemo, u okviru sljedećeg poglavlja, analizirati relevantnu sudsku praksu o UOGI-jima primjenjivu na tehničko-nautičke lučke usluge.

\subsubsection{Relevantna sudska praksa Suda EU-a o UOGI-jima}

Temeljna značajka UOGI-ja jest da se njima postižu učinci koji su od javne dobrobiti, a koje slobodno tržište ne bi pružilo (ili bi pružilo pod drukčijim uvjetima u smislu objektivne kvalitete, sigurnosti, cjenovne prihvatljivosti, jednakog postupanja ili općeg pristupa) bez javne intervencije. ${ }^{39}$ To je takozvani kriterij nefunkcioniranja tržišta (engl. market failure). Odluka o uvođenju konkretnih UOGI-ja prepuštena je širokoj diskreciji država članica. To proizlazi iz primarnog prava Unije. Naime, u čl. 1. Protokola br. 26 UFEU-a daje se tumačenje o tome što uključuju zajedničke vrijednosti Unije u smislu čl. 14. UFEU-a u pogledu UOGI-ja te se ističe široko diskrecijsko pravo nacionalnih, regionalnih i lokalnih tijela u pružanju, naručivanju i organiziranju UOGI-ja. ${ }^{40}$ Ipak, ovlast definiranja UOGI-ja od strane države članice nije neograničena. Ona se ne može

37 Vidi presudu u predmetu C-18/23 Piloti, cit. u bilj. 35, t. 37.

38 Određivanje tarife koja se ne sastoji samo od cijene pružanja usluge priveza i odveza, nego uključuje i troškove pružanja univerzalne usluge priveza i odveza koja je povjerena određenom lučkom poduzetniku dopušteno je ako to povećanje tarife stvarno odgovara dodatnim troškovima prouzročenim pružanjem univerzalne usluge. Predmeti C-266/96 Corsica Ferries/Ormeggatori, cit. u bilj. 30, t. 46, 52 i 60; C-153/93 Bundesrepublik Deutschland v Delta Schiffahrts- und Speditionsgesellschaft mbH., ECLI:EU:C:1994:240, t. 23 i C-38/97 Autotrasporti Librandi Snc di Librandi F. \& C. v Cuttica spedizioni e servizi internationali Srl., ECLI:EU:C:1998:454, t. 37.

39 Komisija je definirala pojam UOGI u skladu s ustaljenom sudskom praksom Suda EU-a. Vidi mišljenje nezavisne odvjetnice E. Sharpston u predmetu C-413/15 Farrell, EU:C:2017:492, t. 90. Vidi Okvir za upravljanje kvalitetom UOGI-ja, cit. u bilj. 11, str. 3; Stanković, op. cit. u bilj. 14, str. 58.

40 Vidi Protokol br. 26 UFEU-u, SL C 202, 7. 6. 2016., str. 307. 
izvršavati arbitrarno s jedinim ciljem uklanjanja određenog sektora iz primjene pravila tržišnog natjecanja. ${ }^{41}$

Komisija može dovesti u pitanje definiciju UOGI-ja samo u slučaju tzv. očite pogreške. Očita pogreška (engl. manifest error) pravni je standard koji Sud EU-a primjenjuje prilikom ocjenjivanja opravdanosti uspostavljanja UOGI-ja. U tom smislu postojanje očite pogreške može se, primjerice, utvrditi ako država članica nije podnijela dokaz o tome da postoji stvarna potreba za javnom uslugom i da je njezin opseg nužan i proporcionalan ili ako nije poštovala te kriterije prilikom propisivanja UOGI-ja. ${ }^{42}$ U pravnoj se teoriji upućuje na sličnost između instituta očite pogreške i instituta izvrtanja ovlasti u upravnom pravu. ${ }^{43}$

Nadalje, diskrecija država članica ograničena je u onim sektorima u kojima je provedena harmonizacija na razini Unije. U tim slučajevima diskrecijska ocjena država članica ne smije biti protivna pravilima o harmonizaciji. ${ }^{44}$ Komisija također može kontrolirati sadržava li naknada za pružanje javne usluge u slučaju UOGI-ja nedopuštene državne potpore te jesu li poštovana važeća pravila o povjeravanju usluga od javnog interesa. Za tehničko-nautičke lučke usluge Komisija će ponajprije primijeniti pravila sektorske Uredbe 2017/352 kao lex specialis. Ako ta Uredba ne sadržava odgovarajuća pravila, tada će se primijeniti opća pravila kojima se uređuje UOGI.

41 Vidi presudu u predmetu BUPA i dr./Komisija, T289/03, EU:T:2008:29, t. 168.

42 Vidi presudu u predmetu T-454/13, SNCM/Komisija, EU:T:2017:134, t. 133. Kao primjer očite pogreške u definiranju UOGI-ja navode se i lučke usluge ukrcaja, iskrcaja, prekrcaja, skladištenja te općenito premještanja robe u lukama koje nisu UOGI jer UOGI, prema stajalištu Suda, pokazuje posebna obilježja u usporedbi s drugim gospodarskim djelatnostima. Predmet C-179/90 Merci convenzionali porto di Genova, cit. u bilj. 30, t. 27.

43 Institut izvrtanja ili izokretanja ovlaštenja spominje se u upravnom pravu u svezi s ocjenom zakonitosti rješenja donesenih po slobodnoj ocjeni. To je situacija kada je nadležno tijelo, rješavajući po diskrecijskoj (slobodnoj) ocjeni, prekoračilo granice ovlaštenja koja su mu dana pravnim propisima i odlučilo suprotno cilju u kojem je ovlaštenje dano, što čini materijalnopravni razlog za vođenje upravnog spora. Vidi Stanković, op. cit. u bilj. 14, str. 58; Pehar, S., Razlozi zbog kojih se upravni akt može pobijati u upravnom sporu, Zbornik radova Pravnog fakulteta u Splitu, vol. 48, br. 1, 2008., str. 125.

44 Također, kada postoje posebna pravila prava Unije kojima je uređeno definiranje sadržaja i opsega UOGI-ja, njih su države članice dužne poštovati pri ocjeni, u skladu s točkom 46. Komunikacije o UOGI-jima, cit. u bilj. 11. 


\subsection{Odredbe Uredbe $2017 / 352$ primjenjive na pitanja pristupa tržištu tehničko-nautičkih lučkih usluga}

Recitalom 11. preambule Uredbe 2017/352 jamči se sloboda pružanja lučkih usluga u morskim lukama na koje se ta Uredba primjenjuje. Međutim, istim recitalom predviđena je mogućnost propisivanja određenih uvjeta pod kojima se sloboda pružanja lučkih usluga može ostvarivati. ${ }^{45} \mathrm{U}$ tom smislu u okviru drugog poglavlja Uredbe 2017/352 regulirano je pružanje lučkih usluga u lukama Unije i pristup tržištu tih usluga te su njezinim čl. 3. propisani uvjeti koje države članice Unije mogu postaviti za pristup tržištu lučkih usluga. To su: minimalni zahtjevi za pružanje lučkih usluga, ograničenja broja pružatelja usluga, obveze pružanja javnih usluga te ograničenja povezana s unutarnjim operaterima. Treba istaknuti kako se Uredba 2017/352 primjenjuje samo na određene vrste lučkih usluga taksativno navedene u njezinu čl. 1. st. 2., koje uključuju opskrbu gorivom, rukovanje teretom, privez, putničke usluge, sakupljanje brodskog otpada i ostataka tereta, peljarenje i tegljenje. Drugo poglavlje Uredbe 2017/352 o pružanju lučkih usluga, sukladno izričitoj odredbi čl. 10. te Uredbe, ne primjenjuje se na usluge rukovanja teretom, putničke usluge ni peljarenje. Države članice mogu odlučiti primijeniti to poglavlje na peljarenje, o čemu su dužne obavijestiti Komisiju. Izuzeće lučkih usluga rukovanja teretom i putničkih usluga rezultat je kompromisa među državama članicama Unije jer neke od njih nisu bile spremne liberalizirati tržište tih usluga koje su od velike gospodarske važnosti. Isto vrijedi i za pitanje samostalnog obavljanja lučkih usluga od strane korisnika luke (engl. self-handling), koje nije uređeno Uredbom 2017/352 zbog otpora sindikata lučkih radnika u nekim državama članicama Unije prema uvođenju tog instituta. ${ }^{46} \mathrm{~S}$ druge strane, izuzimanjem usluga peljarenja od primjene drugog poglavlja Uredbe 2017/352 htjelo se državama članicama omogućiti što veću razinu diskrecije u svezi s organizacijom pružanja te vrste usluga zbog njihove osobite važnosti za sigurnost plovidbe u luci, uzimajući u obzir različitosti morskih luka u Uniji. ${ }^{47}$

Prilikom analize uvjeta, tj. ograničenja koja se mogu primijeniti na pristup tržištu lučkih usluga, posebna pozornost posvetit će se onim uvjetima koji su bitni u kontekstu pristupa tržištu tehničko-nautičkih lučkih usluga tegljenja i

45 De facto to su ograničenja slobode pružanja lučkih usluga.

46 Vidi supra t. 3.

47 U tom smislu u recitalu 24. preambule Uredbe 2017/352 navodi se kako Unija ima širok raspon morskih luka s različitim modelima organizacije pružanja lučkih usluga te kako ne bi bilo prikladno uvođenje jedinstvenog modela pružanja lučkih usluga za sve luke u Uniji. 
priveza i odveza (koje podliježu primjeni drugog poglavlja Uredbe 2017/352) te primjena kojih, po našem mišljenju, može predstavljati izazove za nadležna tijela u državama članicama koja će odlučivati o ispunjavanju uvjeta potrebnih za pristup tržištu tih usluga.

U svezi s minimalnim uvjetima za pružanje lučkih usluga čl. 4. st. 2. propisuje da se oni mogu jedino ${ }^{48}$ odnositi na stručne kvalifikacije pružatelja lučkih usluga, financijsku sposobnost pružatelja lučkih usluga, opremu potrebnu za pružanje odgovarajuće lučke usluge, dostupnost odgovarajuće lučke usluge svim korisnicima, na svim vezovima i bez prekida, danju i noću, tijekom cijele godine $^{49}$, usklađenost sa zahtjevima o pomorskoj sigurnosti ili sigurnosti i sigurnosnoj zaštiti luke ili pristupa luci ${ }^{50}$, usklađenost s lokalnim, nacionalnim, Unijinim i međunarodnim zahtjevima u vezi s okolišem, usklađenost s obvezama u području socijalnog i radnog prava koje se primjenjuje u državi članici u kojoj se nalazi dotična luka te dobar ugled pružatelja lučke usluge.

Kada je riječ o specifičnim minimalnim uvjetima za pružanje lučkih usluga tehničko-nautičkog karaktera, treba istaknuti kako je člankom 4. stavkom 3. Uredbe $2017 / 352$ državama članicama priznato pravo da, ako to smatraju potrebnim kako bi se osigurala potpuna usklađenost s propisima u području socijalnog i radnog prava koje se primjenjuje u određenoj državi članici u kojoj se ta luka nalazi ${ }^{51}$, mogu uvesti zahtjev plovidbe pod zastavom za plovila koja se uglavnom upotrebljavaju za tegljenje ili vezivanje u lukama koje se nalaze na njezinu državnom području. Iako takva odluka nedvojbeno ograničava slobodu pružanja te vrste usluga, njezin je cilj omogućiti državama članicama ostvarivanje strože kontrole nad pružanjem usluga tegljenja i priveza i odveza u lukama na njihovu državnom području, a sve s ciljem postizanja veće razine sigurnosti u obavljanju tih usluga.

Osim toga, stavkom 5. članka 4. Uredbe 2017/352 propisano je da ako minimalni zahtjevi uključuju posebno poznavanje lokalnih uvjeta, upravljačko tijelo

48 Državama članicama zabranjeno je proširivati minimalne uvjete za pružanje lučkih usluga na uvjete različite od onih koji su propisani Uredbom 2017/352.

49 O važnosti ispunjavanja tog uvjeta kod tehničko-nautičkih lučkih usluga vidi supra, t. 2 .

50 U službenom tekstu Uredbe 2017/352, u čl. 4. st. 2. na hrvatskom jeziku spominju se minimalni uvjeti povezani uz "sigurnost i zaštitu luke". Uvidom u njezin tekst na engleskom razvidno je da je zapravo riječ o uvjetima u svezi sa sigurnosnom zaštitom luke (engl. security).

51 Uključujući uvjete primjenjivih kolektivnih ugovora, zahtjeve u pogledu broja osoblja i zahtjeve povezane sa satima rada i satima odmora za pomorce te s primjenjivim pravilima o inspekcijama rada. Vidi čl. 4. st. 1. g. Uredbe 2017/352. 
luke ${ }^{52}$ ili nadležno tijelo ${ }^{53}$ dužno je osigurati odgovarajući pristup informacijama, pod transparentnim i nediskriminirajućim uvjetima. Kao što je prethodno navedeno ${ }^{54}$, poznavanje lokalnih uvjeta od iznimne je važnosti za pružanje tehničko-nautičkih lučkih usluga. U teoriji je već ranije postavljeno pitanje motiviranosti aktualnih pružatelja lučkih usluga da svoja znanja o lokalnim uvjetima prenose konkurentima..$^{55}$ Naime, potencijalni pružatelji tehničko-nautičkih lučkih usluga koji žele steći znanja o lokalnim uvjetima ta će znanja moći steći jedino od zaposlenika aktualnog pružatelja tih usluga, koji često ima monopolni položaj na tržištu tehničko-nautičkih usluga u određenoj luci. Nerealno je očekivati da će zaposlenici aktualnog pružatelja usluga u luci svoja znanja prenositi na osobe koje su im izravni konkurenti i koje im kasnije zbog toga mogu oduzeti posao. Jednaka je situacija i u slučaju kada tehničko-nautičke lučke usluge pružaju zaposlenici upravljačkog tijela luke, lučke uprave, što dovodi u pitanje provedivosti tog uvjeta u praksi.

S obzirom na to da su lučka područja zemljopisno ograničena, broj pružatelja lučkih usluga može u određenim slučajevima ovisiti o ograničenjima u vezi s nedostatkom zemljišta ili obalnog prostora te značajkama lučke infrastrukture. U tom smislu člankom 6. Uredbe 2017/352 predviđeno je da upravljačko tijelo luke ili nadležno tijelo može ograničiti broj pružatelja lučkih usluga za određenu lučku uslugu iz jednog ili više taksativno navedenih razloga koji obuhvaćaju nedostatak ili rezerviranu upotrebu zemljišta ili obalnog prostora, kada nepostojanje ograničenja broja pružatelja lučke usluge ometa izvršavanje obveza pružanja javnih usluga, među ostalim kada nepostojanje tog ograničenja uzrokuje pretjerano visoke troškove u vezi s izvršavanjem obveza javne usluge upravljačkom tijelu luke, nadležnom tijelu ili korisnicima luke, kada je nepostojanje ograničenja broja pružatelja lučke usluge protivno potrebi za osiguravanjem sigurnog ili okolišno održivog rada luka te kada su značajke lučke

52 Upravljačko tijelo luke je svako javno ili privatno tijelo koje na temelju nacionalnog prava ima za cilj ili je ovlašteno na lokalnoj razini, bilo zajedno s drugim djelatnostima ili bez njih, administrirati i upravljati lučkom infrastrukturom te izvršavati jedan ili više sljedećih zadataka u toj luci: koordinaciju lučkog prometa, upravljanje lučkim prometom te koordinaciju i kontrolu aktivnosti operatera prisutnih u luci (čl. 2. t. 5. Uredbe 2017/352).

53 Nadležno tijelo je svako javno ili privatno tijelo koje u ime lokalne, regionalne ili nacionalne razine ima pravo obavljati, na temelju nacionalnog prava, aktivnosti povezane s organizacijom i administracijom lučkih djelatnosti, u suradnji s upravljačkim tijelom luke ili umjesto njega (čl. 2. t. 3. Uredbe 2017/352).

54 Vidi supra, t. 2.

55 Munari, op. cit. u bilj. 26, str. 61; Bulum, B., Usluge pomorskog prijevoza i lučke djelatnosti u pravu tržišnog natjecanja Europske zajednice, Inmag, Zagreb, 2010., str. 212. 
infrastrukture ili priroda lučkog prometa takve da djelatnosti više pružatelja lučkih usluga u luci ne bi bile moguće. Ako upravljačko tijelo luke ili nadležno tijelo odluči ograničiti broj pružatelja lučkih usluga, ono je dužno provesti postupak propisan stavcima 2. - 6. članka 6. Uredbe 2017/352, odnosno objaviti prijedlog ograničenja broja pružatelja lučke usluge barem tri mjeseca prije donošenja odluke o takvom ograničenju, objaviti donesenu odluku o ograničenju te provesti transparentan i nediskriminirajući postupak odabira lučkog operatera koji mora biti otvoren svima zainteresiranima.

U kontekstu pristupa tržištu tehničko-nautičkih usluga kao usluga za pružanje kojih države članice mogu nametnuti obvezu pružanja javne usluge, česta je situacija u praksi da nepostojanje ograničenja broja pružatelja lučke usluge može ometati izvršavanje obveza pružanja javnih usluga tako što uzrokuje pretjerano visoke troškove u vezi s izvršavanjem tih obveza upravljačkom tijelu luke, nadležnom tijelu ili korisnicima luke. Naime, karakteristika je tehničko-nautičkih usluga da za tim uslugama postoji uvijek približno jednaka potražnja u određenoj luci, pa se ekonomija obujma i učinkovitost njihova obavljanja može postići jedino ako je broj pružatelja usluge ograničen. ${ }^{56}$

Zbog toga se te usluge često povjeravaju jednom poduzetniku za čitavu luku, tzv. univerzalnom poduzetniku. U većim lukama u kojima je potražnja za tehničko-nautičkim uslugama dovoljno velika poželjno je dopustiti ulazak na tržište većem broju lučkih poduzetnika kako bi se potaknula konkurencija, pod uvjetom da to neće ugroziti pružanje univerzalne usluge.

U odredbe Uredbe 2017/352 ugrađena su stajališta sudske prakse o pružanju usluga tehničko-nautičkog karaktera te je odredbom čl. 7. te Uredbe propisano kako države članice mogu odlučiti pružateljima lučkih usluga nametnuti obveze pružanja javnih usluga povezane s lučkim uslugama kako bi osigurale ostvarenje barem jednog od sljedećih ciljeva. To su: dostupnost lučke usluge svim korisnicima luke, na svim vezovima i bez prekida danju i noću, tijekom cijele godine, dostupnost usluge svim korisnicima pod jednakim uvjetima, pristupačnost usluge za određene kategorije korisnika, sigurnost, sigurnosnu zaštitu ili okolišnu održivost rada luka, pružanje odgovarajućih usluga prijevoza javnosti i teritorijalnu koheziju. U tom slučaju upravljačko tijelo luke ili nadležno tijelo provodi postupak odabira pružatelja lučke usluge, osim u slučaju poremećaja u pružanju lučkih usluga za koje su nametnute obveze pružanja javnih usluga kada upravljačko tijelo luke ili nadležno tijelo može poduzeti tzv. hitne mjere. Hitne mjere mogu uključivati izravno dodjeljivanje lučke usluge na način da se ta usluga dodijeli drugom pružatelju usluga na razdoblje do dvije godine.

56 Riječ je o prirodnim monopolima. Vidi Carbone, Munari, op. cit. u bilj. 10, str. 202. 
Člankom 6. stavkom 6. propisano je da ako upravljačko tijelo luke ili nadležno tijelo pruža lučke usluge samo ${ }^{57}$ ili putem zasebne pravne osobe koju izravno ili neizravno nadzire, država članica tada poduzima mjere potrebne za izbjegavanje sukoba interesa. ${ }^{58} \mathrm{U}$ slučaju nepostojanja takvih mjera broj pružatelja usluga ne smije biti manji od dva, osim ako su ispunjeni uvjeti za ograničenje broja pružatelja lučkih usluga iz čl. 6. st. 1. Uredbe 2017/352.

Nadalje, člankom 8. Uredbe 2017/352 propisano je da upravljačko tijelo luke ili nadležno tijelo može odlučiti da će lučku uslugu pružati samo ili putem zasebne pravne osobe nad kojom obavlja stupanj nadzora sličan onom koji ima nad vlastitim odjelima, tzv. unutarnjeg operatera ${ }^{59}$, pod uvjetom da se čl. 4 . o minimalnim uvjetima za pružanje lučke usluge primjenjuje na sve pružatelje te lučke usluge.

\section{PRAVNO UREĐENJE PRISTUPA TRŽIŠTU TEHNIČKO-NAUTIČKIH LUČKIH USLUGA U HRVATSKOM PRAVU}

Pitanje pristupa tržištu lučkih usluga uključujući i tržištu usluga tehničko-nautičkog karaktera u RH poglavito je uređeno odredbama Zakona o pomorskom dobru i morskim lukama. ${ }^{60}$ Člankom 66. ZPDML-a propisano je kako se pravo na obavljanje lučkih djelatnosti, korištenje postojeće podgradnje i nadgradnje te gradnje novih građevina i drugih objekata podgradnje i nadgradnje stječe na temelju koncesije. Koncesija za obavljanje lučkih djelatnosti može se dodijeliti pravnoj i fizičkoj osobi registriranoj za obavljanje obrta, koja ispunjava ZPDML-om propisane uvjete. Duljina koncesijskog razdoblja te postupak dodjele

57 Situaciju u kojoj upravljačko tijelo luke samo ili samostalno pruža lučke usluge korisnicima luke (engl. managing body of the port provides a port service itself) treba razlikovati od samostalnog obavljanja lučkih usluga od strane korisnika luke (engl. self-handling).

58 Takve bi mjere, među ostalim, mogle imati oblik povjeravanja donošenja odluka o ograničenju broja pružatelja lučkih usluga mjerodavnom nacionalnom tijelu neovisnom o upravljačkom tijelu luke ili nadležnom tijelu. Vidi recital 27. Uredbe $2017 / 352$.

59 Vidi čl. 8. st. 2. Uredbe 2017/352 i čl. 12. Direktive 2014/24/EU Europskog parlamenta i Vijeća od 26. veljače 2014. o javnoj nabavi i o stavljanju izvan snage Direktive 2004/18/EZ (SL L 94, 28. 3. 2014., str. 65 - 242) kojim je kodificirana sudska praksa Suda EU-a te su regulirani slučajevi u kojima javni ugovor koji javni naručitelj dodijeli drugoj pravnoj osobi ne pripada u područje primjene te Direktive.

60 Narodne novine, br. 158/2003, 100/2004, 141/2006, 38/2009, 123/2011, 56/2016, 98/2019 (dalje u tekstu: ZPDML). 
koncesije ovisi o tome zahtijeva li koncesija za obavljanje lučkih djelatnosti, odnosno ostalih gospodarskih djelatnosti isključivo korištenje postojećih i/ili gradnju novih građevina i drugih objekata podgradnje i nadgradnje na lučkom području ili ne. ${ }^{61}$

Iz navedenog slijedi kako je pružanje lučkih usluga u hrvatskim lukama u cijelosti preneseno na privatni sektor te da lučke uprave ne bi trebale sudjelovati u pružanju tih usluga, odnosno da one nemaju funkciju lučkog operatera ${ }^{62}$ već one, prema važećem ZPDML-u, imaju isključivo ulogu kućevlasnika (engl. landlord) odgovornog, među ostalim, za koordinaciju pružanja lučkih djelatnosti, bez sudjelovanja u njihovu pružanju. ${ }^{63}$

Međutim, u poslovnoj praksi luka otvorenih za javni promet to se pravilo ne poštuje. Lučke se uprave u posljednjem desetljeću u sve većoj mjeri bave pružanjem usluga veza plovila nautičkog turizma. U posljednje vrijeme one su počele pružati i usluge veza plovila koja se koriste $u$ javnom linijskom pomorskom prijevozu, osobito u lukama otvorenim za javni promet od županijskog i lokalnog značaja te za to naplaćivati tzv. dodatak pristojbi za vez. U nekima od tih luka usluge priveza i odveza brodova linijski su brodari niz godina obavljali samostalno. Ograničenje prava linijskih brodara da samostalno obavljaju usluge priveza i odveza naišlo je na njihovo neodobravanje. Ponajprije zato što plaćanje dodatka pristojbi na vez za njih predstavlja dodatno financijsko opterećenje, koje nije zanemarivo. Također, lučke uprave usluge priveza i odveza ne pružaju kontinuirano, već samo u uredovnom vremenu lučke uprave, tako da linijski brodari i dalje obavljaju privez i odvez svojih brodova samostalno u vrijeme kada zaposlenici lučke uprave zaduženi za privez i odvez brodova u luci ne rade. ${ }^{64}$ Stoga se brodari (s pravom) pitaju zbog čega članovi posade njihovih brodova ne bi mogli vršiti privez i odvez tih brodova kontinuirano, kao što su to uspješno obavljali već desetljećima, a da nikada nije bila ugrožena sigurnost luke, te koji je cilj recentne organizacije pružanja usluga priveza i odveza.

${ }^{61}$ U prvom slučaju koncesija se dodjeljuje na rok do 99 godina na temelju javnog prikupljanja ponuda, dok se u drugom slučaju ona dodjeljuje na zahtjev tražitelja koncesije na rok do 10 godina. Vidi čl. 67. ZPDML-a.

62 Člankom 78. stavkom 2. ZPDML-a iznimka je predviđena za luke otvorene za javni promet lokalnog značaja u kojima ne postoji gospodarski interes za pružanje usluga prihvata otpada, opskrbe vodom i električnom energijom. Te usluge može pružati lučka uprava.

63 Vidi Bulum, B., Zajednička europska lučka politika - prošlost i recentne mjere u njezinom uspostavljanju, Zbornik radova Pravnog fakulteta u Splitu, vol. 46., br. 2, 2009., str. 349.

64 Lučke uprave nisu osigurale pružanje univerzalne usluge priveza i odveza, što nalaže zaštita općeg interesa sigurnosti plovidbe u luci. 
Pravila Unije primjenjiva na pitanja organizacije pružanja tehničko-nautičkih lučkih usluga u RH obuhvaćaju ponajprije pravila Uredbe 2017/352 ${ }^{65}$ kojom je reguliran pristup tržištu usluga priveza/odveza i tegljenja te sudsku praksu Suda EU-a koja se odnosi na pružanje tehničko-nautičkih usluga i UOGI-ja. Čl. 6. st. 6. i čl. 8. Uredbe 2017/352 predviđaju mogućnost da upravljačko tijelo luke ili nadležno tijelo, tj. lučka uprava ${ }^{66}$, samo pruža lučke usluge ili putem zasebne pravne osobe koju izravno ili neizravno nadzire ili da to može činiti putem unutarnjeg operatera, uz ispunjavanje uvjeta propisanih tom Uredbom. ${ }^{67}$ Međutim, lučke uprave u RH prilikom donošenja odluke o tome da usluge priveza i odveza obavljaju same nisu postupile u skladu s čl. 6. st. 6. i čl. 8. Uredbe 2017/352. U svezi s primjenom čl. 6. st. 6. Uredbe 2017/352 u konkretnom slučaju treba napomenuti kako nije utvrđeno postojanje uvjeta za ograničenje broja pružatelja lučkih usluga iz čl. 6. st. 1. Uredbe 2017/352. ${ }^{68}$

Također, lučke uprave nisu postupile ni u skladu s člankom 8. Uredbe 2017/352, koji u slučaju kada lučke uprave odluče lučku uslugu pružati samostalno ili putem zasebne pravne osobe nad kojom obavljaju stupanj nadzora sličan onom koji imaju nad vlastitim odjelima upućuje na primjenu članka 4. te Uredbe o minimalnim uvjetima za pružanje lučke usluge koji, među ostalim, uključuju obvezu osiguravanja dostupnosti lučke usluge svim korisnicima, na svim vezovima i bez prekida, danju i noću, tijekom cijele godine (čl. 4. st. 2. d Uredbe 2017/352).

Lučke su uprave odluku da će usluge priveza i odveza obavljati same donijele jednostrano, bez poduzimanja bilo kakvih mjera za izbjegavanje sukoba interesa iz čl. 6. st. 6. Uredbe 2017/352, pa tako donošenje odluke o ograničenju broja pružatelja lučkih usluga nije bilo povjereno mjerodavnom nacionalnom tijelu neovisnom o lučkoj upravi. ${ }^{69}$ Također, broj pružatelja lučkih usluga, protivno odredbi čl. 6. st. 6. Uredbe 2017/352 bio je manji od dva jer su se brodari bili dužni koristiti uslugama priveza i odveza koje su pružali zaposlenici lučke uprave

65 Republika Hrvatska donijela je Zakon o provedbi Uredbe 2017/352, kojim su utvrđena nacionalna tijela nadležna za njezinu provedbu, postupci po pritužbama, savjetovanje te prekršajne odredbe. Vidi Narodne novine, br. 66/2019.

66 Upravljačko tijelo luke ili nadležno tijelo u RH je lučka uprava koja upravlja lukom otvorenom za javni promet (čl. 3. st. 1. Zakona o provedbi Uredbe 2017/352), loc. cit.

67 Vidi supra, t. 3. 2.

68 Opširnije o uvjetima za ograničenje broja pružatelja lučkih usluga vidi supra, t. 3. 2.

69 Ta mjera za izbjegavanje sukoba interesa predviđena je 27. recitalom Uredbe 2017/352, međutim, hrvatski Zakon o provedbi Uredbe 2017/352 nije odredio mjerodavno nacionalno tijelo u ovom slučaju zato što prema hrvatskom ZPDML-u lučke uprave nisu pružatelji lučkih usluga, osim u iznimnim slučajevima, vidi bilj. 62 . 
za trajanja uredovnog vremena lučke uprave. Naime, lučke su uprave tvrdile kako samostalno obavljanje lučkih usluga priveza i odveza od strane brodara odnosno članova posade brodova koji uplovljavaju u luke i isplovljavaju iz njih ugrožava sigurnost luka. Međutim, izvan uredovnog vremena lučkih uprava brodari su i dalje samostalno obavljali privez i odvez za svoje potrebe. Iz navedenog proizlazi kako lučke uprave nisu osigurale pružanje univerzalne usluge priveza i odveza, tj. njezino pružanje u bilo koje vrijeme, odnosno i u vrijeme kada lučka uprava ne ureduje, svim korisnicima luke, što nalaže zaštita općeg interesa sigurnosti plovidbe u luci. Zaključak je kako lučke uprave prilikom donošenja odluke o tome da usluge priveza i odveza obavljaju same nisu poštovale relevantne odredbe Uredbe 2017/352.

Štoviše, sve da su lučke uprave i postupile prema odredbama Uredbe 2017/352 prilikom donošenja odluke da će usluge priveza i odveza pružati same, takva bi odluka bila protivna odredbama nacionalnog prava. Naime, kao što je navedeno ranije u ovom poglavlju, odredbama važećeg ZPDML-a Hrvatska se opredijelila za kućevlasnički model vlasništva i upravljanja lukama prema kojem lučke uprave nemaju funkciju pružatelja lučkih usluga. Kako je 24. recitalom Uredbe 2017/352 $2^{70}$ državama članicama Unije dana mogućnost da na nacionalnoj razini odaberu model organizacije pružanja lučkih usluga, odredbe ZPDML-a u ovom slučaju imaju prednost pred odredbama Uredbe 2017/352. Odredbe Uredbe 2017/352 o postupanju u slučaju kada upravljačko tijelo luke ili nadležno tijelo, tj. lučka uprava, samo pruža lučke usluge, primijenit će se u onim državama članicama Unije koje su se odlučile za modele alatnih (engl. tool ports) ili servisnih (engl. service ports) luka kod kojih lučke uprave imaju i funkciju lučkog operatera. ${ }^{71}$

Uredbom 2017/352 nije regulirano pitanje samostalnog obavljanja bilo koje vrste lučkih usluga od strane korisnika luke, pa tako ni usluga tehničko-nautičkog karaktera. Stoga je rješenja spornih pitanja potrebno potražiti u relevantnoj sudskoj praksi Suda EU-a. Iz sudske prakse proizlazi kako nadležna nacionalna tijela mogu propisati obvezu korištenja korisnika luke tehničko-nautičkim lučkim uslugama (svim ili jednom vrstom tih usluga) te zabraniti njihovo samostalno obavljanje korisnicima luke ako je to opravdano radi zaštite javne sigurnosti. S druge strane, države članice Unije u formuliranju pravila o tehničko-nautičkim lučkim uslugama kao UOGI-jima imaju širok stupanj diskrecije, no ona ipak nije neograničena, odnosno ne može se izvršavati arbitrarno s jedinim ciljem uklanjanja određenog sektora iz primjene pravila tržišnog natjecanja. Također,

$70 \quad$ Vidi bilj. 47.

71 Vidi Bulum, op. cit. u bilj. 63, str. 349. 
država članica dužna je podnijeti dokaz o tome da postoji stvarna potreba za javnom uslugom i da je njezin opseg nužan i proporcionalan te poštovati te kriterije prilikom propisivanja UOGI-ja. Nadalje, javna tijela, odlučujući po diskrecijskoj ocjeni ne smiju prekoračiti granice ovlaštenja koja su im dana pravnim propisima i donositi odluke suprotno cilju u kojem im je to ovlaštenje dodijeljeno. U slučaju tehničko-nautičkih lučkih djelatnosti cilj radi kojeg je javnim tijelima dodijeljeno ovlaštenje odlučivanja po diskrecijskoj osnovi je zaštita općeg interesa sigurnosti plovidbe u lukama te posljedično sigurnosti osoba, lučkih uređaja i postrojenja, zaštita okoliša i sigurnosna zaštita luka koji se ostvaruje organizacijom pružanja te vrste usluga za konkretnu luku koja jamči ostvarenje tih ciljeva. Stjecanje dobiti pružanjem usluga tehničko-nautičkog karaktera trebalo bi biti od sekundarne važnosti.

Usluge tegljenja i peljarenja u hrvatskim lukama pružaju privatni lučki poduzetnici na temelju ugovora o koncesiji. Osim ZPDML-om, pristup tržištu usluga tegljenja i peljarenja reguliran je i odredbama Pomorskog zakonika (dalje u tekstu: PZ). ${ }^{72}$ Odredbom čl. 641. PZ-a propisano je kako tegljenje koje počinje i završava se u hrvatskim lukama ili u unutarnjim morskim vodama i teritorijalnom moru RH (kabotažno tegljenje) ne mogu obavljati strani brodovi bez odobrenja ministra. Ova odredba nije u suglasju s Uredbom 2017/352 u dijelu koji se odnosi na lučko tegljenje jer se njome zahtijeva prethodno odobrenje za pružanje te vrste usluga i za brodare iz Unije. Ograničenje pristupa tržištu usluga tegljenja dopušteno je samo uz primjenu uvjeta propisanih drugim poglavljem Uredbe 2017/352. Člankom 4. stavkom 3. te Uredbe državama članicama Unije dopušteno je uvođenje zahtjeva plovidbe pod zastavom za plovila koja se uglavnom upotrebljavaju za tegljenje ili vezivanje u lukama koje se nalaze na njezinu državnom području kako bi se osigurala usklađenost s propisima u području socijalnog i radnog prava primjenjivim u toj državi članici. Stoga bi odredbe PZ-a o pristupu tržištu usluga lučkog tegljenja trebalo uskladiti s Uredbom 2017/352. Kako države članice Unije prema Uredbi 2017/352 nisu dužne liberalizirati tržište peljarenja, RH se odlučila za opciju ograničenog pristupa tržištu tih usluga za strane operatere. Tako je člankom 69. PZ-a propisana obveza ishođenja prethodnog odobrenja ministra za strane pravne osobe zainteresirane za pružanje usluga peljarenja, a njegovim stavkom 2. propisano je kako će se to odobrenje izdati samo u slučaju kada peljarenje ne može ili ne želi obaviti domaća pravna osoba. Osim PZ-om, usluge pomorskog peljarenja regulirane su i Pravilnikom o pomorskom peljarenju. ${ }^{73}$ Tim su Pravilnikom, među ostalim,

72 Narodne novine, br. 181/2004, 76/2007, 146/2008, 61/2011, 56/2013, 26/2015, 17/2019.

73 Pravilnik o pomorskom peljarenju, Narodne novine, br. 116/2010, 43/2018. 
detaljno propisani uvjeti koje moraju zadovoljavati brod i zapovjednik kako bi mogli biti oslobođeni obveznog peljarenja. ${ }^{74}$ Kada je riječ o drugim lučkim uslugama tehničko-nautičkog karaktera, pravnim propisima RH nije regulirano pitanje njihova samostalnog obavljanja. Kako je takva situacija postala izvor sporova u praksi (osobito u svezi s uslugama priveza i odveza), a relevantna pravila ne sadržava ni Uredba 2017/357, smatramo kako bi trebalo razmisliti o donošenju nacionalnih propisa kojima bi se reguliralo pitanje samostalnog obavljanja tehničko-nautičkih lučkih usluga. U skladu sa sudskom praksom Suda EU-a, samostalno obavljanje tehničko-nautičkih usluga moglo bi se dopustiti onim brodarima koji poznaju lokalne uvjete, mogu te usluge obavljati kontinuirano i imaju za to kvalificirano osoblje.

\section{ZAKLJUČAK}

Donošenjem Uredbe 2017/352 pružanje lučkih usluga u morskim lukama Unije prvi je put regulirano njezinim sekundarnim pravom. U tu je Uredbu velikim dijelom ugrađena jurisprudencija Suda EU-a u svezi s pružanjem tehničko-nautičkih lučkih usluga. Ustaljena je sudska praksa Suda EU-a kako su tehničko-nautičke lučke usluge obuhvaćene konceptom univerzalne usluge te kako su one UOGI, tj. javne usluge. Posljedično, države članice imaju pravo intervenirati na tržište tih usluga kako bi osigurale njihovu dostupnost (engl. availability) svim korisnicima luke u bilo koje vrijeme. Uredbom 2017/352 nije regulirano pitanje samostalnog obavljanja bilo koje vrste lučkih usluga od strane korisnika luke (engl. self-handling), pa tako ni usluga tehničko-nautičkog karaktera. Stoga je rješenja spornih pitanja potrebno potražiti u relevantnoj sudskoj praksi Suda EU-a. Iz sudske prakse proizlazi kako nadležna nacionalna tijela mogu propisati obvezu korištenja korisnika luke tehničko-nautičkim lučkim uslugama (svim uslugama ili jednom vrstom tih usluga) te zabraniti njihovo samostalno obavljanje korisnicima luke ako je to opravdano radi zaštite javne sigurnosti. Također, u skladu s čl. 6. st. 6. i čl. 8. Uredbe 2017/352 upravljačko tijelo luke ili nadležno tijelo može odlučiti da će lučke usluge, uključujući i tehničko-nautičke usluge tegljenja i priveza i odveza pružati samo ili putem zasebne pravne osobe koju izravno ili neizravno nadzire ili putem tzv. unutarnjeg lučkog operatera, uz ispunjavanje uvjeta propisanih tom Uredbom. Države članice Unije u formuliranju pravila o tehničko-nautičkim lučkim uslugama

74 Osim propisanih tehničkih karakteristika broda, ključno je poznavanje lokalnih uvjeta od strane njegova zapovjednika koje se provjerava teorijskim i praktičnim ispitom. Vidi članke 8., 25. i 38. Pravilnika. 
kao UOGI-jima imaju širok stupanj diskrecije, no ona ipak nije neograničena. Ovlast definiranja UOGI-ja od strane države članice ne može se arbitrarno izvršavati s jedinim ciljem da se ukloni određeni sektor iz primjene pravila tržišnog natjecanja. Uz to, nadležna javna tijela ne smiju prekoračiti granice ovlaštenja koja su im dana pravnim propisima i donositi odluke suprotno cilju u kojem im je to ovlaštenje dodijeljeno. Kod usluga tehničko-nautičkog karaktera taj je cilj ponajprije zaštita općeg interesa sigurnosti plovidbe u lukama i na plovnim putovima za pristup lukama te posljedično sigurnosti osoba, lučkih uređaja i postrojenja, zaštita okoliša i sigurnosna zaštita luka, a pritom je stjecanje dobiti pružatelja lučke usluge od sekundarne važnosti.

Temeljni zakon kojim je regulirano pružanje lučkih usluga u RH je ZPDML. Kao što je ranije navedeno ${ }^{75}$, iz odredbi ZPDML-a proizlazi kako je pružanje lučkih usluga u hrvatskim lukama povjereno privatnom sektoru na temelju ugovora o koncesiji te da lučke uprave ne bi trebale sudjelovati u pružanju tih usluga ${ }^{76}$ Člankom 78. stavkom 2. ZPDML-a predviđena je vrlo uska iznimka od tog pravila koja se odnosi samo na luke otvorene za javni promet od lokalnog značaja i iznimkom nije obuhvaćeno pružanje usluga tehničko-nautičkog karaktera. Slijedom navedenog, prema važećem hrvatskom pravu lučke uprave nisu ovlaštene same pružati tehničko-nautičke usluge.

Kao što je prethodno pojašnjeno ${ }^{77}$, lučke uprave u RH prilikom donošenja odluke o tome da usluge priveza i odveza obavljaju same nisu postupile u skladu s čl. 6. st. 6. i čl. 8. Uredbe 2017/352. Međutim, sve da su lučke uprave i postupile prema odredbama Uredbe 2017/352 prilikom donošenja odluke da će usluge priveza i odveza pružati same, takva bi odluka bila protivna odredbama nacionalnog prava zato što prema odredbama važećeg ZPDML-a lučke uprave nemaju funkciju pružatelja lučkih usluga. Kako je 24. recitalom Uredbe 2017/352 državama članicama Unije dana mogućnost da na nacionalnoj razini odaberu model organizacije pružanja lučkih usluga, odredbe ZPDML-a u ovom slučaju imaju prednost pred odredbama Uredbe 2017/352.

Kada je riječ o samostalnom obavljanju usluga tehničko-nautičkog karaktera od strane brodara, treba istaknuti kako ono pravnim propisima RH nije regulirano, osim za usluge peljarenja. Pravilnikom o pomorskom peljarenju RH detaljno su razrađeni uvjeti koje moraju zadovoljavati brod i zapovjednik kako bi mogli biti oslobođeni obveznog lučkog peljarenja. Iz Pravilnika o pomorskom peljarenju proizlazi kako je za oslobođenje od obveznog peljarenja, osim propi-

\footnotetext{
75 Opširnije vidi supra, t. 4.

76 Vidi čl. 66. st. 2. ZPDML-a.

77 Vidi supra, t. 4.
} 
sanih tehničkih karakteristika broda, potrebno poznavanje lokalnih uvjeta od strane njegova zapovjednika, koje se provjerava teorijskim i praktičnim ispitom. Kako ni Uredba 2017/357 ne sadržava pravila o samostalnom obavljanju lučkih usluga, smatramo da bi Hrvatska trebala donijeti vlastite propise kojima bi se reguliralo pitanje samostalnog obavljanja usluga priveza i odveza. U skladu sa sudskom praksom Suda EU-a, jednako kao i kod usluga peljarenja, samostalno obavljanje tehničko-nautičkih usluga priveza i odveza moglo bi se dopustiti onim brodarima koji poznaju lokalne uvjete, mogu te usluge obavljati kontinuirano i imaju na raspolaganju za to kvalificirano osoblje.

Ostaje napomenuti kako je bez obzira na vrstu i pravni status lučkog operatera kojem je povjereno pružanje tehničko-nautičkih lučkih usluga on dužan te usluge pružati kontinuirano, bez prekida (engl. provision on round the clock - round the year basis) i svim brodovima u luci. To proizlazi iz relevantne sudske prakse Suda EU-a ${ }^{78}$, autoritativne pravne doktrine ${ }^{79}$ te čl. 4. st. 2. d Uredbe 2017/352, u kojem se kao jedan od minimalnih uvjeta koje upravljačko tijelo luke ili nadležno tijelo može zahtijevati od pružatelja lučkih usluga navodi obveza osiguravanja dostupnosti lučke usluge svim korisnicima, na svim vezovima i bez prekida, danju i noću, tijekom cijele godine.

Smatramo kako bi odredbe ZPDML-a trebalo dopuniti pravilima kojima bi se precizno regulirali uvjeti čije ispunjavanje će RH tražiti od lučkih operatera za pristup tržištu tehničko-nautičkih lučkih usluga u svojim lukama otvorenim za javni promet, u skladu s Uredbom 2017/352 i sudskom praksom Suda EU-a.

Vezano uz pružanje lučkih usluga (pa tako i onih tehničko-nautičkog karaktera) od strane lučkih uprava, smatramo da bi se nadležni u RH trebali opredijeliti ili za zadržavanje postojećeg kućevlasničkog modela, prema kojem lučke uprave nemaju funkciju lučkog operatera i osiguravanje njegove dosljedne primjene, ili za legalizaciju prava lučkih uprava da same pružaju određene vrste lučkih usluga u lukama pod svojom upravom. U tom slučaju trebala bi se također jasno propisati prava i obveze lučkih uprava kao pružatelja lučkih usluga.

Opširnije vidi supra, t. 3. 1.

79 U tom smislu vidi osobito bilj. 32. 


\section{LITERATURA}

\section{Knjige i članci:}

Bulum, B., Pravo tržišnog natjecanja Europske zajednice i morske luke, Zbornik Pravnog fakulteta u Zagrebu, vol. 58, br. 1-2, 2008., str. 617 - 661.

Bulum, B., Usluge pomorskog prijevoza i lučke djelatnosti u pravu tržišnog natjecanja Europske zajednice, Inmag, Zagreb, 2010.

Bulum, B., Zajednička europska lučka politika - prošlost i recentne mjere u njezinom uspostavljanju, Zbornik radova Pravnog fakulteta u Splitu, vol. 46, br. 2, 2009., str. $337-358$.

Carbone, M. S.; Munari, F., Port services ancillary to navigation between market and safety requirements, Lloyd's Maritime and Commercial Law Quarterly, br. 1, 1996., str. 67 - 91.

Carbone, M. S.; Munari, F., The Regime of Technical-Nautical services (Pilotage, Towage, Mooringmen) under European law u: Van Hooydonk, E. (ur.), European Seaports Law, EU Law of Ports and Ports Services and the Ports Package, Malu, Antwerpen-Apeldoorn, 2003., str. 187 - 206.

Ćapeta, T.; Rodin, S., Osnove prava Europske unije, III. izmijenjeno i dopunjeno izdanje, Narodne novine, Zagreb, 2018.

De Groot, M., Supervision on Public Service Performance by Private Providers: the Relevance of EU Law, European Procurement \& Public Private Partnership Law Review, vol. 10, br. 4, 2015., str. 243 - 253.

Grabovac, I., Plovidbeno pravo Republike Hrvatske, Književni krug, Split, 2006.

Ivošević, B.; Pejović, Č., Pomorsko pravo, Pravni fakultet Univerziteta Union u Beogradu, Javno poduzeće Službeni glasnik, Beograd, 2019.

Jakaša, B., Udžbenik plovidbenog prava, II. Izdanje, Narodne novine, Zagreb, 1983.

Leiren, M. D.; Parkes, L., When trade unions succeeded: Cases of blocked liberalisation in the common market, European Journal of Political Research, vol. 53, br. 1, 2014., str. 465 - 479, doi:10.1111/1475-6765.12044

Munari, F., The impact on technical-nautical services of the second proposal for a port service directive, Il dritto marittimo, br. 1., 2006., str. 48 - 64 .

Pavić, D., Pomorsko imovinsko pravo, Književni krug, Split, 2006.

Pehar, S., Razlozi zbog kojih se upravni akt može pobijati u upravnom sporu, Zbornik radova Pravnog fakulteta u Splitu, vol. 48, br. 1, 2008., str. 101 - 127.

Radionov, N. et al., Europsko prometno pravo, Pravni fakultet Sveučilišta u Zagrebu, Zagreb, 2011. 
Radionov, N., Financiranje univerzalne usluge širokopojasnog pristupa internetu: novi izazovi za Hrvatsku, Zagrebačka pravna revija - Elektronički časopis poslijediplomskih studija Pravnog fakulteta Sveučilišta u Zagrebu, vol. 6, br. 2, 2017., str. 147 - 174.

Stanković, D., Uloga postupaka javne nabave u financiranju usluga od općeg gospodarskog interesa, Zagrebačka pravna revija - Elektronički časopis poslijediplomskih studija Pravnog fakulteta Sveučilišta u Zagrebu, vol. 7, br. 1, 2017., str. 53 - 69.

Van Hooydonk, E., The European Port Services Directive: the Good or the Last Try?, Il diritto marittimo, br. 1., 2006., str. 65 - 111.

Van Hooydonk, E., The Regime of Port Authorities under European Law (including an Analysis of Port Services Directive) u: Van Hooydonk, E. (ur.), European Seaports Law, EU Law of Ports and Ports Services and the Ports Package, Malu, Antwerpen-Apeldoorn, 2003., str.79 - 61.

\section{Pravni akti:}

Ugovor o funkcioniranju Europske Unije, SL C 202, (pročišćeni tekst), 7.6.2016., str. $47-201$.

Ugovor o Europskoj Uniji, SL C 202, (pročišćeni tekst), 7.6.2016. str. 13 - 47.

Protokol br. 26 Ugovor o funkcioniranju Europske unije, SL C 202, 7.6.2016, str. $307-308$.

Uredba (EU) 2017/352 Europskog Parlamenta i Vijeća od 15. veljače 2017. o uspostavi okvira za pružanje lučkih usluga i zajedničkih pravila o financijskoj transparentnosti luka, SL L 57, 3.3.2017, str. 1 - 18.

Direktiva Vijeća 96/67/EZ od 15. listopada 1996. o pristupu tržištu zemaljskih usluga u zračnim lukama Zajednice, SL L 272, 25.10.1996, str. 36 - 45.

Direktiva 2014/24/EU Europskog parlamenta i Vijeća od 26. veljače 2014. o javnoj nabavi i o stavljanju izvan snage Direktive 2004/18/EZ, SL L 94, 28.3.2014, str. $65-242$.

Pomorski zakonik, Narodne novine, br. 181/04, 76/07, 146/08, 61/11, 56/13,26/15, $17 / 19$.

Zakon o pomorskom dobru i morskim lukama, Narodne novine, br. 158/2003, 100/04, 141/06, 38/09, 123/11, 56/16, 98/19.

Pravilnik o pomorskom peljarenju, Narodne novine, br. 116/10, 43/18. 


\section{Sudska praksa:}

C- 118/85 Komisija/Italija, ECLI:EU:C:1987:283,

C-179/90, Merci convenzionali porto di Genova SpA v Siderurgica Gabrielli SpA., ECLI:EU:C:1991:464

C-179/90 Silvana Raso i dr., ECLI:EU:C:1998:54

C-18/93 i Corsica Ferries Italia Srl v Corpo dei Piloti del Porto di Genova, ECLI:EU:C:1994:195

C-153/93 Bundesrepublik Deutschland v Delta Schiffahrts- und Speditionsgesellschaft mbH., ECLI:EU:C:1994:240

C-35/96 Komisija/Italija, ECLI:EU:C:1998:303

C-266/96 Corsica Ferries France SA/Gruppo Antichi Ormeggiatori del porto di Genova Coop. arl, Gruppo Ormeggiatori del Golfo di La Spezia Coop. i dr., ECLI:EU:C:1998:306

C-38/97 Autotrasporti Librandi Snc di Librandi F. \& C. v Cuttica spedizioni e servizi internationali Srl., ECLI:EU:C:1998:454

Spojeni predmeti 430/99 i C-431/99, Inspecteur van de Belastingdienst Douane, district Rotterdam v Sea-Land Service Inc. and Nedlloyd Lijnen BV., ECLI:EU:C:2002:364 T289/03 BUPA i dr./Komisija, EU:T:2008:29

T-454/13, SNCM/Komisija, EU:T:2017:134

C-413/15, Farrell, EU:C:2017:492 
Summary

\author{
Božena Bulum* \\ Marija Pijaca**
}

\title{
LEGAL REGULATION OF THE ACCESS TO THE TECHNICAL-NAUTICAL PORT SERVICES MARIKET IN EU AND CROATIAN LAW AND ITS PRACTICAL CONSEQUENCES
}

This paper deals with the matters of market access and the organisation of the provision of technical-nautical port services in EU and Croatian law. Since 1997, when the Green Paper on Seaports and Maritime Infrastructure (Green Paper) was adopted and the enactment of European legislation applicable to the port sector was announced, these issues have caused numerous disputes among stakeholders. Consequently, the first European Union secondary law act on market access to port services, Regulation 2017/352 establishing a framework for the provision of port services and common rules on the financial transparency of ports (Regulation 2017/352) was enacted twenty years after the Green Paper. However, with that Regulation the issue of market access to technical-nautical port services is only partially regulated. For that reason, besides the Regulation 2017/32, other relevant sources of EU and Croatian law are analysed in this paper, and proposals for their improvements are presented.

Keywords: technical-nautical port services; market access; Regulation 2017/352; universal services; services of general economic interest

* Božena Bulum, Ph. D., Scientific Adviser, Adriatic Institute of the Croatian Academy of Sciences and Arts, Augusta Šenoe 4, Zagreb; bbulum@hazu.hr; ORCID ID: orcid.org/0000-0003-4606-9815

* Marija Pijaca, Ph. D., Assistant Professor, Maritime Department, University of Zadar, Mihovila Pavlinovića 1, Zadar;mpijaca@unizd.hr;

ORCID ID: orcid.org/0000-0002-0709-376X 
